\section{Vel verdt en titt}

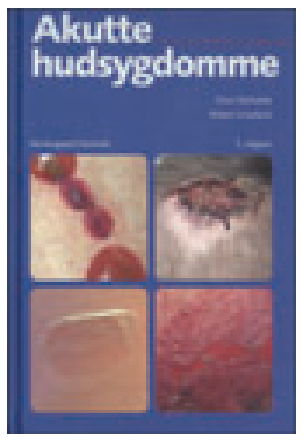

Claus Zachariae, Robert Gniadecki Akutte hudsygdomme

2. utg. 212 s, tab, ill. København: Munksgaard Danmark, 2011. Pris DKK 278

ISBN 978-87-628-1017-4

«Kunne du bare ta en kikk på dette?» Spørsmålet kommer ofte fra en pasient eller en rådvill kollega som står overfor et akutt hudproblem. Og et nyoppstått utslett kan være vanskelig. Diagnosene er mange, og det kan være en utfordring å vite hvor man skal begynne å lete når man står fast.

Den lille danske boken Akutte hudsygdomme ble utgitt første gang i 2004. I denne andreutgaven er det lagt til sju nye sykdomsbeskrivelser, og illustrasjonene er forbedret. Målgruppen er alle leger som møter pasienter med akutte hudsykdommer, særlig vakthavende på sykehus, legevakt eller i allmennpraksis.

Det er 16 sykdomskapitler som er inndelt etter utslettenes kliniske bilde, eksempelvis makuløse, papuløse, pustuløse og eksematøse utslett. De forskjellige typene utslett som forfatterne omtaler, defineres og illustreres innledningsvis. Deretter følger kapitler hvor forfatterne beskriver tilstandene. Sykdomspanoramaet dekkes godt, med beskrivelse av over 90 tilstander. De kortfattede beskrivelsene er inndelt i definisjon, målgruppe, klinikk, differensialdiagnoser, undersøkelser, behandling og eventuelt behov for videre henvisning. Alle tilstandene er illustrert med fargefotografier. Bidragsyterne avslutter med en rekke tabeller hvor bl.a. hudsykdommer hos gravide, nyfødte og immunsupprimerte, hudsykdommer etter utenlandsreise, medikamentelle utslett, hudsykdommer genitalt, sykdommer oralt og akutte hårtap beskrives.

Jeg synes dette er en god bok som treffer målgruppen. Inndelingen etter klinisk bilde og en god innholdsfortegnelse gjør det lett å navigere og dermed komme på sporet av en diagnose. Forfatterne forklarer innledningsvis at de enkelte tilstandene innenfor ett kapittel presenteres etter avtakende hyppighet. Tanken er god, men følges ikke helt opp. I kapitlet om erosjoner kommer intertrigo til slutt, etter langt sjeldnere tilstander som SSSS (staphylococcal scalded skin syndrome) og toksisk epidermal nekrolyse. Forfatterne tar for seg de fleste akutte hudlidelsene, men jeg kunne nok ha ønsket at seboreisk dermatitt fikk en separat omtale. Særlig når tilstander som heparin nekrose, calcifylaksi og morbus Schamberg får plass.

Beskrivelsene av de enkelte tilstandene er konsise og gode, spesielt avsnittene som omhandler klinikk og differensialdiagnoser. Behandlingsavsnittene er nyttige, men blir av og til for summariske. Her ville et supplerende kapittel om korrekt bruk og nedtrapping av lokale steroider ha hjulpet. I avsnittet om behandling av intertrigo nevnes «hudplejemidler»; det blir for uspesifikt. Illustrasjonene er representative og gode. Hvis jeg skulle ønsket meg noe, måtte det være flere bilder av pasienter med mørk hud, da en del av tilstandene kan arte seg annerledes hos disse. Tabellene som presenteres avslutningsvis, er ypperlige. Boken er lett og rask å lese, og gir gode muligheter for et økt diagnostisk repertoar. Anbefales!

\section{Dermatologiske forelesningsnotater}

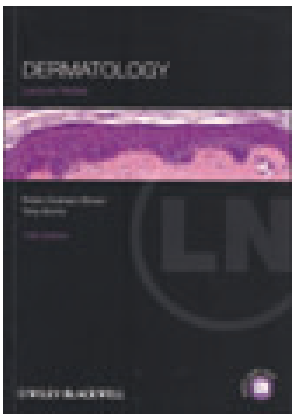

\author{
Robin Graham-Brown, Tony Burns \\ Dermatology
}

Lecture notes. 10. utg. 224 s, ill. Chichester: Wiley-Blackwell, 2011. Pris GBP 23 ISBN 978-1-4051-9571-3

Det finnes flere gode lærebøker, skrevet av britiske hudleger, beregnet på medisinstudenter, allmennleger og sykepleiere som arbeider med hudpasienter. Slike bøker har et stort marked, ettersom britisk dermatologi holder et høyt faglig nivå, og fordi engelsk er første fremmedspråk i store deler av verden.

En av disse bøkene er nå kommet i sin 10. utgave: Dermatology. Lecture notes. De to forfatterne er erfarne klinikere. Kapittelinndelingen er den samme som i tidligere utgaver og nokså tradisjonell, men et nytt kapittel om akutt dermatologi er lagt til. Nesten alle kapitlene innledes med et litterært sitat, bl.a. fra Shakespeare, Dostojevski og Det nye testamentet, eller med utsagn fra ukjente kilder, gjerne humoristiske. Også i selve teksten har forfatterne her og der utsagn som man skjønner er brukt i forelesningssammenheng. Teksten er godt gjennomarbeidet og lett å lese. Boken har mange og gode kliniske fotografier og figurer, foruten tekstrammer med viktige hovedpunkter. Det hele avsluttes med noen kasusoppgaver og en nyttig ordliste.

Tilnærmingen er klinisk. Vanlige sykdommer er gitt bredere omtale, mens mer sjeldne sykdommer bare er omtalt kortfattet, slik det bør være. De siste årenes nyvinninger med bruk av selektive immunmodulerende legemidler, såkalte biologika, mot kroniske inflammatoriske hudsykdommer, særlig psoriasis, er med, men omtalen er relativt kort og overfladisk. Dette kan forsvares med at slike legemidler bare forskrives av spesialister.

Særlig godt likte jeg kapitlet om klinisk undersøkelse med den utmerkede overskriften Approach to the diagnosis of dermatological disease - riktig diagnose nås gjennom en god anamnese og en strukturert og systematisk beskrivelse av de kliniske funnene. Dermatologisk status bør beskrives like strukturert og systematisk som indremedisinsk status. Her slurves det mye i daglig praksis, dessverre. Forfatternes behandlingsforslag samsvarer stort sett med norsk praksis. Seksuelt overførte sykdommer omtales ikke i Storbritannia er dermatologi og venerologi to atskilte spesialiteter.

Boken omfatter den kunnskap som norske medisinstudenter forventes å ha om hudsykdommer til eksamen, men er på enkelte områder noe mer detaljert. Den er aktuell for dem som synes det er greit med engelskspråklige lærebøker. Venerologisk kunnskap må de skaffe seg andre steder. Boken er også egnet for allmennleger som en oppdatering, men ikke for dem som søker mer inngående kunnskap om diagnostikk og behandling av hudsykdommer.

\section{Petter Gjersvik}

Seksjon for hudsykdommer

Oslo universitetssykehus, Rikshospitalet 